\title{
TECTONOPHYSICAL EVIDENCES OF GEODYNAMIC EVOLUTION OF THE PRIKOLYMA TERRAIN (NORTH-EASTERN REGIONS OF RUSSIA)
}

\author{
A. N. Glukhov ${ }^{1}$, A. S. Gladkov², D. A. Koshkarev², O. V. Lunina² \\ ${ }^{1}$ Northeastern Interdisciplinary Scientific Research Institute, Far East Branch of RAS, Magadan, Russia \\ ${ }^{2}$ Institute of the Earth's Crust, Siberian Branch of RAS, Irkutsk, Russia
}

\begin{abstract}
The Prikolyma terrain is a part of the Yana-Kolyma orogenic belt located in the North Eastern Asia. It is generally composed of the Proterozoic deposits, including sandstones, metapellites, quartz-feldspar and carbonate rocks, meta- and hyperbasites. The Prikolyma terrain represents a fragment of passive margin of the North-Asian craton that was detached in the Middle Paleozoic due to progressing rifting. Subsequent geological development of the terrain was determined by accretion events at its boundary with margin of the North-Asian craton and the Omolon microcraton. Its long-term geodynamic evolution is reflected in the character and sequence of formation of the Prikolyma terrain deformation structures.

In the central part of the Prikolyma terrain, i.e. in the basin of the Malaya Stolbovaya river, two reference areas of tectonics were studied, which contain packs of thrust sheets complicated by subsequent high-angle faults. The fault pattern is complex, and its major elements are gently dipping zones of plastic deformation, which mark the boundaries of petrographically heterogenous plates. The thrust packs are more than $200 \mathrm{~m}$ thick; their root zones are represented by series of highangle reverse faults. Another important element of the fault pattern is high-angle zones of brittle deformation, which kinematic characteristics are ambiguous. A vertical component of displacement is predominant for the faults of the north-western strike; a strike-slip component is characteristic of latitudinal and meridional faults. The fault pattern developed in several stages under the impact of fields of tectonic stress, which vectors were variable.
\end{abstract}

The folds, comprising a uniform structural paragenesis with thrusts, are of great importance for the structure under study. The largest folds exhibit the asymmetric structure with the NE dipping axial planes. Axes of smaller folds are oriented to NW and N-NW.

Four stages of deformation are distinguished in the history of geological development of the Prikolyma terrain. The earliest stage was characterized by the NE compression resulting in formation of the NW-oriented thrusts and folds and zones of greenschiest dynamo-metamorphism. During the second stage, the axis of compression gained the E-NE orientation, and the axis of extension was oriented to the N-NW, which influenced the formation of the submeridional reverse faults and thrusts. During the third stage, the axis of compression was NW oriented, and the axis of extension gained the NE orientation. Thereat, the sublatitudinal and submeridional structures were activated as strike-slip faults, the NW structures as normal faults, and the NE structures as reverse faults. The above resulted in the formation of structures of volume extension, which are favorable for localization of magmatic bodies and ore streaky-veined structures. At the final stage, compression in the meridional direction lead to the formation of thrusts and reverse faults along the sublatitudinal displacements, normal faults along the submeridional displacements, and strike-slips along the NE and NW displacements.

The first deformation stage was contemporaneous with the long-term period of compression in the Riphean and Early Paleozoic, when the dynamo-metamorphic complex of the Prikolyma terrain was developed. In the second stage, the Prikolyma terrain was detached from the margin of the North-Asian craton. In the Early Cretaceous, the third stage took place, when rearrangements of the field of tectonic stresses and transition to conditions of general extension caused emplacement of granitoids and quartz veining. The NW orientation of the compression vector suggests that the third stage was related to the regional tangential compression due to the asymmetrical collision of the Prikolyma terrain and the Omolon microcraton. In the final stage, rotation of the vector of compression, associated with development of numerous NW and NE-oriented fractures, reflected the occurrence of the epiorogenic rifting.

The above-described stages of formation of the deformation structure of the Prikolyma terrain are evidently correlated with the main tectono-magmatic stages of development of the NE margin of the North-Asian craton, which took place in the Late Paleozoic and the Mesozoic.

Key words: Prikolyma terrain, structure geology, faults, tectonophysics.

Recommended by K.Zh. Seminsky 3 December 2012

Citation: Glukhov A.N., Gladkov A.S., Koshkarev D.A., Lunina O.V., 2012. Tectonophysical evidences of geodynamic evolution of the Prikolyma terrain (North-Eastern regions of Russia). Geodynamics \& Tectonophysics 3 (4), 361-375. doi:10.5800/GT-2012-3-4-0079. 


\title{
ТЕКТОНОФИЗИЧЕСКИЕ КРИТЕРИИ ГЕОДИНАМИЧЕСКОЙ ЭВОЛЮЦИИ ПРИКОЛЫМСКОГО ТЕРРЕЙНА (СЕВЕРО-ВОСТОК РОССИИ)
}

\author{
А. Н. Глухов ${ }^{1}$, А. С. Гладков ${ }^{2}$, Д. А. Кошкарев ${ }^{2}$, О. В. Лунина ${ }^{2}$ \\ ${ }^{1}$ Северо-Восточный комплексный научно-исследовательский институт ДВО РАН, Магадан, Россия \\ ${ }^{2}$ Институт земной коры СО РАН, Иркутск, Россия
}

\begin{abstract}
Аннотация: Приколымский террейн является составной частью Яно-Колымского орогенного пояса северо-востока Азии. Он сложен главным образом протерозойскими образованиями: песчаниками, метапелитами, кварц-полевошпатовыми и карбонатными породами, метабазитами и гипербазитами. Приколымский террейн представляет собой фрагмент пассивной окраины Северо-Азиатского кратона, отторгнутый в среднем палеозое вследствие прогрессировавшего рифтинга. Дальнейшее геологическое развитие террейна определялось аккреционными событиями на его границах с окраиной Северо-Азиатского кратона и Омолонским микрократоном. Длительная геодинамическая эволюция нашла свое отражение в характере и последовательности образования деформационных структур Приколымского террейна.
\end{abstract}

Изучены два опорных участка земной коры в центральной части Приколымского террейна (бассейн р. Малая Столбовая), представляющих собой пакеты надвиговых чешуй, осложненные поздними крутопадающими разломами. Сеть разломов имеет сложное строение. Одним из основных ее элементов являются пологие зоны пластических деформаций, маркирующие границы петрографически разнородных тектонических пластин. Мощности надвиговых пакетов превышают 200 м, а их корневые зоны представлены сериями крутопадающих взбросов. Другим важным элементом разломной сети являются крутопадающие зоны хрупких деформаций. Их кинематические характеристики неоднозначны. У дизъюнктивов северо-западного простирания преобладает вертикальная компонента смещения, у широтных и меридиональных - сдвиговая. Формирование сети разрывных нарушений происходило в течение нескольких этапов под действием различных полей тектонических напряжений.

Большую роль в структуре играют складки, образующие единый парагенез с надвигами. Наиболее крупные из них имеют асимметричное строение с падением осевых плоскостей на северо-восток. Оси более мелких складок ориентированы в северо-западном и север-северо-западном направлениях.

В истории геологического развития Приколымского террейна выделены четыре деформационных этапа. Наиболее ранний характеризовался сжатием в северо-восточном направлении, в результате которого образовались надвиги и складки северо-западной ориентировки, зоны зеленосланцевого динамометаморфизма. На втором этапе ось сжатия приобрела восток-северо-восточную ориентировку, а растяжения - север-северо-западную, что отразилось в формировании субмеридиональных взбросов и надвигов. В течение третьего этапа ось сжатия имела северо-западную, а ось растяжения - северо-восточную ориентировку. Субширотные и субмеридиональные структуры при этом активизировались как сдвиги, северо-западные - как сбросы, а северо-восточные - как взбросы. В результате формировались структуры объемного растяжения, благоприятные для локализации магматических тел и прожилково-жильных образований. На завершающем этапе сжатие в меридиональном направлении привело к образованию надвигов и взбросов по субширотным нарушениям, сбросов - по субмеридиональным, сдвигов - по северо-восточным и северозападным. Первый деформационный этап параллелизуется с крупной рифейско-раннепалеозойской эпохой сжатия, сформировавшей динамометаморфический комплекс Приколымского террейна. Второй этап отразил обособление Приколымского террейна от окраины Северо-Азиатского кратона. В раннем мелу перестройка поля тектонических напряжений и переход к условиям общего растяжения на третьем этапе привели к внедрению гранитоидов и формированию зон кварцевого прожилкования. Северо-западная ориентировка вектора сжатия позволяет увязать этот этап с региональным тангенциальным сжатием в результате косой коллизии Приколымского террейна с Омолонским микрократоном. На завершающем этапе поворот вектора сжатия с образованием многочисленных трещин северозападной и северо-восточной ориентировки отразил проявление эпиорогенного рифтогенеза.

Выделенные этапы формирования деформационной тектонической структуры Приколымского террейна четко параллелизуются с главными тектономагматическими этапами развития северо-восточной окраины Северо-Азиатского кратона - позднепалеозойским и мезозойским.

Ключевые слова: Приколымский террейн, структурная геология, разломы, тектонофизика.

\section{1. ВВЕДЕНИЕ}

Приколымский террейн (рис. 1) является составной частью Яно-Колымского орогенного пояса [Khanchuk, 2006a; Parfenov et al., 2003] и протягивается в субмеридиональном направлении более чем на 450 км. В соответствии с существующими представлениями, он является фрагментом пассивной окраины Северо-Азиатского кратона, отторгнутым в палеозое вследствие прогрессировавшего рифтогенеза [Khanchuk, 2006b; Shpikerman, 1998]. Дальнейшее геологическое развитие Приколымского террейна определялось аккреционно-коллизионными событиями на окраине СевероАзиатского кратона, связанными с возникновением 


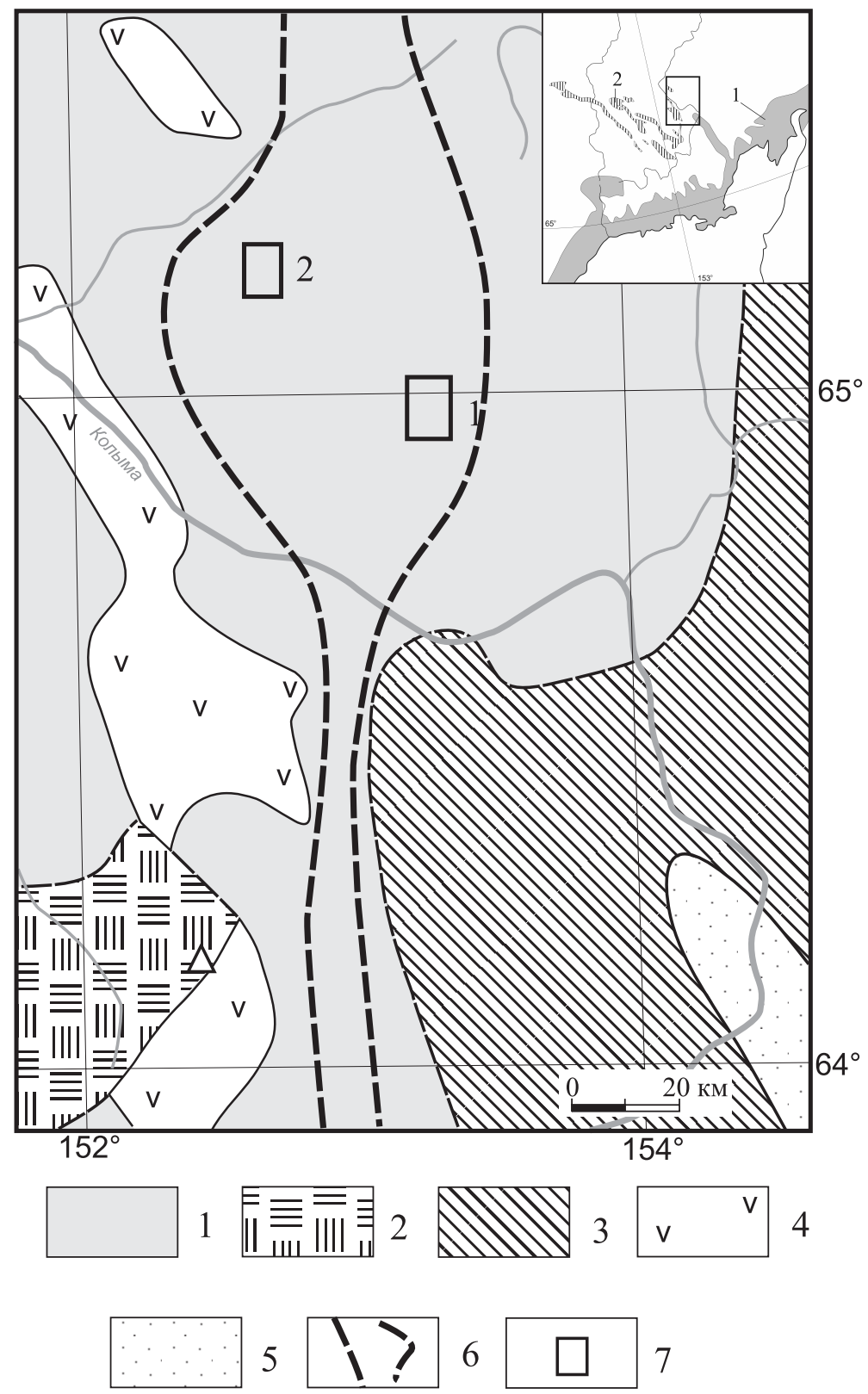

Рис. 1. Тектоническая схема Центрального Приколымья (по [Shpikerman, 1998], с упрощениями и дополнениями). 1 - Приколымский террейн пассивной континентальной окраины; 2 - Аргатасско-Поповкинский океанический террейн; 3 - Яно-Колымский складчатый пояс; 4 - Уяндино-Ясачненский вулканогенный пояс; 5 - Омсукчанский рифт; 6 - границы Приколымского динамометаморфического пояса; 7 - участки структурных исследований (1 - Надежда, 2 - Тимша). На врезке: 1 - Охотско-Чукотская вулканогенная область; 2 Уяндино-Ясачненский вулканогенный пояс.

Fig. 1. The tectonic scheme of the Central Prikolyma (according to [Shpikerman, 1998], with simplifications and additions). 1 - Prikolyma terrain of the passive continental margin; 2 - Argatassko-Popovkinsky oceanic terrain; 3 - Yana-Kolyma folded belt; 4 - Uyandino-Yasachnensky volcanic belt; 5 - Omsukchansky rift; 6 - Prikolyma dynamo-metamorphic belt; 7 - site of structural studies (1 - Nadezhda; 2 - Timsha). In the insert: 1 - Okhotsk-Chukotka volcanic area; 2 - Uyandino-Yasachnensky volcanogenic belt.

Яно-Колымского орогенного пояса. Это формирование энсиалической островной дуги Уяндино-Ясачненского вулканогенного пояса в поздней юре и коллизия Приколымского террейна с Омолонским микрократоном в раннем мелу, которая привела к существенной перестройке структурного плана региона будущего Приколымья. В позднемеловое время террейн был затронут процессами, связанными с формированием Омсукчан- ского рифта.

Столь длительная и насыщенная история геологической эволюции Приколымского террейна должна была найти отражение в составе и строении тектонических структур. Большинство современных исследователей рассматривают Приколымский террейн как пакет надвиговых чешуй, образованный в результате последовательно возобновлявшихся аккреционно-кол- 
лизионных событий: предположительно позднерифейского [Tkachenko, Shcherbakova, 1991], раннепалеозойского [Shpikerman et al., 2001], позднемезозойского [Khanchuk, 2006a; Горячев, 1998; Shpikerman, 1998] возраста. Другими исследователями Приколымский террейн рассматривается как пример жестких, консолидированных структур, по стилю дислоцированности близких к срединным массивам [Akimova, 2006; Rukovich, Kolodeznikov, 2006; Protopopov, Kirillin, 1991; Grinberg et al., 1981]. Деформационная структура террейна при этом интерпретируется как блоковая, определяемая сетью главным образом крутопадающих разломов, вследствие высокой консолидированности субстрата проникающих на значительные глубины [Protopopov, Kirillin, 1991].

Обоснованность тех или иных суждений о характере геодинамической эволюции Приколымского террейна может быть подтверждена только детальными геолого-структурными исследованиями. Такие исследования были проведены нами в центральной части Приколымского террейна, в бассейне р. Малая Столбовая. Здесь полоса выходов докембрийских метаморфизованных комплексов достигает наибольшей ширины, что позволяет оптимально выбрать эталонные участки для изучения. Последние характеризуются сравнительно удовлетворительной обнаженностью. Благодаря проведению здесь интенсивных геологоразведочных работ участки вскрыты многочисленными поверхностными горными выработками - магистральными канавами длиной в сотни метров и скважинами колонкового бурения на глубину до 300 м. Структурно-геологическое картирование, включая геологические маршруты, изучение горных выработок и керна скважин, специализированные тектонофизические исследования разломных структур, их внутреннего строения и кинематики, выделение составных элементов разломов позволили составить обоснованное представление о строении участка и реконструировать историю его формирования. Результаты геологического изучения остальной площади центральной части Приколымского террейна, ограниченной реками Колыма, Шаманиха и Большая Столбовая, позволили обоснованно экстраполировать данные по опорным участкам за их пределы.

\section{2. КРАТКИЙ ОЧЕРК ГЕОЛОГИЧЕСКОГО СТРОЕНИЯ}

Приколымский террейн сложен в различной степени метаморфизованными протерозойскими образованиями: песчаниками, метапелитами, кварц-полевошпатовыми и карбонатными породами, метабазитами. Они несогласно перекрываются неметаморфизованными терригенными, вулканогенно-осадочными и карбонатными породами верхнего палеозоя и позднеюрскими вулканогенными и лагунно-молассовыми отложениями. Стратифицированные комплексы прорваны еди- ничными интрузиями девонских и меловых гранитоидов, а также многочисленными дайками позднемеловых базитов.

Геологическая структура Приколымского террейна представляет собой пакет тектонических чешуй [Shpikerman, 1998]. Падение плоскостей надвигов, разделяющих тектонические пластины, центриклинальное, на западе - восточное (рис. 2), на востоке - западное, под углами $15-35^{\circ}$, и, как правило, близко к залеганию слоистости. Надвиги восточного падения являются синметаморфическими и представляют собой зоны рассланцевания, смятия и бластеза мощностью до первых сотен метров. Метаморфические сланцеватость и полосчатость среди докембрийских образований в основном субпараллельны реликтовой слоистости пород, а интенсивность их проявления в целом убывает с запада на восток, согласуясь со снижением степени динамометаморфизма пород. Выделяется развитие не менее двух систем сланцеватости [Shishkin, 1979], причем одна из них, как правило, параллельна осевым плоскостям микроскладок, а другая - слоистости. Структурный рисунок палеозойских толщ определяют тектонические чешуи с западным падением плоскостей надвигов, представленных зонами катаклаза и редко - милонитизации. Мезозойские отложения залегают преимущественно субгоризонтально, лишь изредка образуя открытые линейные и брахиформные складки [Shishkin, 1979; Shpikerman, 1998].

Центральной части Приколымского террейна пространственно соответствует Приколымский динамометаморфический пояс [Tkachenko, Shcherbakova, 1991; Shishkin, 1979]. В его пределах обнажены преимущественно докембрийские образования, метаморфизованные в условиях зеленосланцевой, эпидот-амфиболитовой и амфиболитовой фаций. Метаморфизм носит зональный характер и относится к дистен-силлиманитовому фациальному типу [Shishkin, 1979]. Среди метаморфических пород многочисленны «реликтовые» участки относительно слабоперекристаллизованных осадочных и магматических пород с хорошо сохранившимися первичными текстурами.

В пределах опорных участков стратифицированные образования представлены исключительно литостратиграфическими подразделениями протерозоя. Все они затронуты неравномерно проявленным динамометаморфизмом зеленосланцевой фации. В строении разреза принимают участие образования чебукулахской (мраморизованные известняки, доломиты и карбонатные сланцы) серии среднего рифея, хакдонской (метаморфизованные риолиты и базальты), уянканской (метаморфизованные вулканомиктовые песчаники и туффиты) серий верхнего рифея, а также породы сяпякинской (песчаники и кварц-серицитовые сланцы) свиты венда (рис. 2, 3).

Интрузивные образования на опорных участках исследований представлены редкими маломощными (до 1 м) дайками позднемеловых долеритов. 


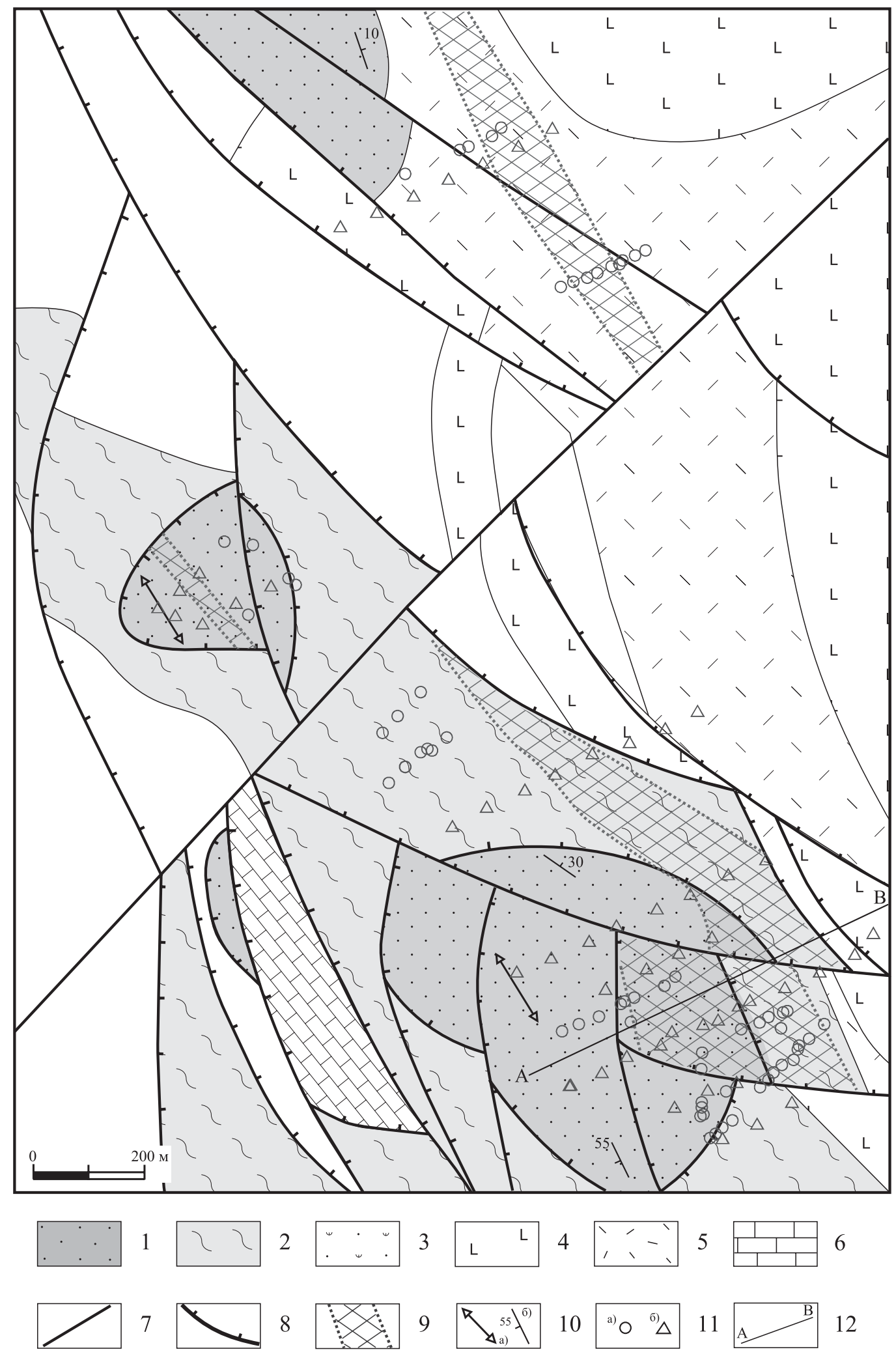

Рис. 2. Геолого-структурная схема опорного участка Надежда. 1-2 - сяпякинская свита: 1 - песчаники, 2 - кварц-серицитовые сланцы; 3 - вулканомиктовые метапесчаники и метатуффиты уянканской серии; 4-5 хакдонская серия: 4 - метабазальты, 5 - метариолиты; 6 мраморизованные известняки, доломиты чебукулахской серии; 7 - разломы сдвиговой природы; 8 - надвиги; 9 - зоны кварцевого прожилкования; 10 - ориентировка шарниров складок (а), элементы залегания слоистости (б); 11 - точки геолого-структурных наблюдений (а) и пробуренные скважины (б); 12 - линия разреза на рис. 3.

Fig. 2. The geological and structural scheme of Nadezhda Reference Site. 1-2 - Syapyakinskaya suite (1 - sandstones, 2 - quartz-sericite schists); 3 - volcanomictous meta-sandstones and meta-tuffites of Uyankanskaya series; 4-5 - Khakdonskaya series (4 - metabasalts, 5 - meta-rhyolites); 6 - marmorized limestones and dolomites of Chebukulakhskaya series; 7 - strike-slip faults; 8 - thrusts; 9 - quartz-streaking zones; 10 - orientations of fold hinges (a), and stratification elements (б); 11 - geological and structural monitoring sites (a) and drilled wells (б); 12 - line of the profile given in Fig. 3. 
A
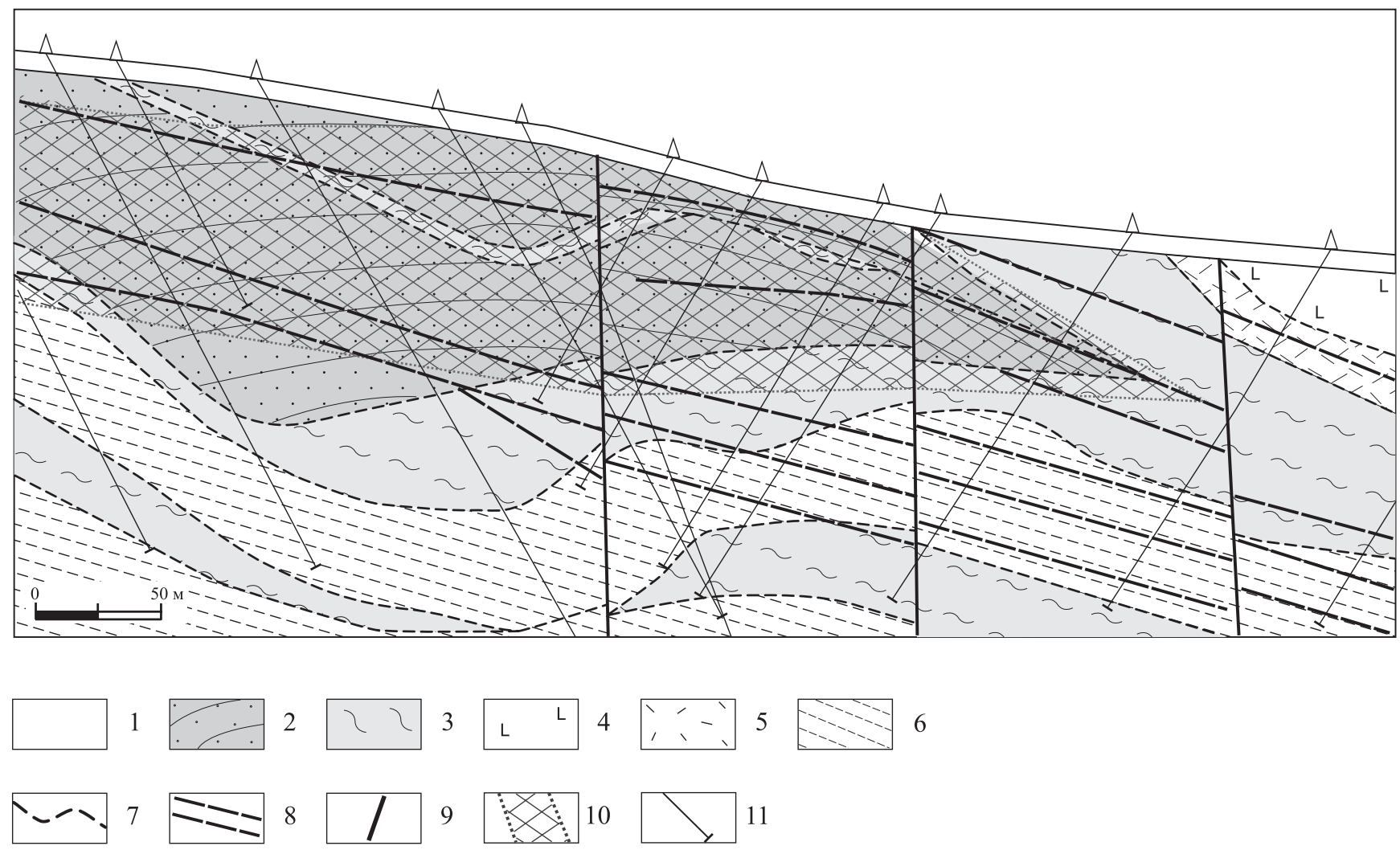

Рис. 3. Геолого-структурный разрез опорного участка Надежда. Горизонтальный масштаб соответствует вертикальному. 1 - рыхлые четвертичные отложения; 2-3 - сяпякинская свита: 2 - песчаники, 3 - кварц-серицитовые сланцы; 4-5 хакдонская серия: 4 - метабазальты, 5 - метариолиты; 6 - хлорит-серицитовые сланцы юкагирской серии; 7 - зоны интенсивного рассланцевания и смятия надвиговой природы; 8 - пологие зоны дробления взбросовой природы; 9 - субвертикальные разломы сдвиговой и сбросовой природы; 10 - зоны кварцевого прожилкования; 11 - скважины.

Fig. 3. The geological and structural profile of Nadezhda Reference Site. The horizontal and vertical scales are consistent. $1-$ loose Quaternary sediments; 2-3 - Syapyakinskaya suite (2 - sandstones; 3 - quartz-sericite schists); 4-5 - Khakdonskaya series (4 - meta-basalts, 5 - metarhyiolites); 6 - chlorite-sericite schists of Yukagirskaya series; 7 - zones of intense schistosity and shearing due to thrusting; 8 - low-angle zones of crushing due to reverse thrusting; 9 - subvertical shear and normal faults; 10 - quartz-streaking zones; 11 - wells.

\section{3. МЕТОДИКА ИССЛЕДОВАНИЙ}

Для решения поставленной задачи использовались полевые тектонофизические методы, позволяющие картировать зоны разрывных нарушений различных рангов, выявлять структуры и/или их ансамбли (парагенезисы), восстанавливать поля тектонических напряжений, определяющие кинематику, и, в конечном счете, характеризовать внутреннее строение разломных зон на различных этапах их развития и активизации. Основой для реализации этих методов служат создаваемые в процессе полевых работ точки наблюдений, в пределах которых выполняется комплекс однотипных тектонофизических и геолого-структурных измерений.

Всего в ходе полевых исследований на изучаемых опорных участках, а также в их окрестностях была создана сеть из 70 точек наблюдений. Фактический материал, полученный за пределами опорных участков, позволил проследить по простиранию отдельные разрывные нарушения, выявленные при детальных иссле- дованиях, а также оценить, насколько особенности его разрывной структуры отражают специфику дислоцированности горных пород всей площади исследования.

Схема производства наблюдений включала в себя привязку точки на плане, определение основных систем трещин и измерение элементов их залегания. Кроме того, документировались взаимоотношения трещин друг с другом. Далее на точке наблюдения проводилось изучение дизъюнктивных структур более крупного по отношению к трещинам масштаба, т.е. локальных разрывных нарушений, если таковые присутствовали в обнажении. Их документация подразумевала измерение элементов залегания, характеристику особенностей вещественного и структурного заполнения, типа контактов с вмещающей средой, морфологию сместителей, а также обязательное измерение количественных параметров (видимая мощность, амплитуда смещения и другие). Помимо дизъюнктивных структур, детально характеризовались складки, будины, линейность и т.д. 
Затем производится массовый замер элементов залегания тектонических трещин, которые измерялись в пределах произвольно выбранной документируемой площадки с обязательным указанием их генетической разновидности (сколовая или отрывная). Опыт наших предыдущих работ свидетельствует, что оптимальным количеством для используемых в дальнейших построениях методов анализа является замер 80-100 трещин. При наличии признаков перемещения блоков горных пород на поверхности трещины также документировались ориентировки штрихов (или борозд), проводилось описание самой поверхности скольжения (морфология, распределение заполнителя по плоскости и т.д.), а также определялся (если это было возможно) знак смещения.

Изучение количественных параметров трещинной сети включало подсчет числа трещин (длиной более 0.1 м) на площадке $1 \mathrm{~m}^{2}$, оценку среднего расстояния между трещинами соизмеримой длины для каждой из систем, а также фиксацию параметров отдельных трещин (длина, зияние, амплитуда смещения).

Для обработки и анализа собранных данных использовались как известные программные продукты (SURFER, RockWorks15), так и оригинальная разработка лаборатории тектонофизики ИЗК СО РАН программный комплекс «Структура 2.0». Данный комплекс предназначен для построения, обработки и анализа структурных диаграмм по замерам трещин и разрывных нарушений. В нем реализованы основные методы выделения и анализа сопряженных систем трещин [Gzovsky, 1975; Parfenov, Parfenova, 1980; Nikolaev, 1977], а также метод определения линий смещения по разрывным нарушениям [Danilovich, 1961; Gladkov, Seminsky, 1999]. Для построения и оформления разломных схем использовались программы CorelDraw и AutoCAD.

\section{4. РЕЗУЛЬТАТЫ ИССЛЕДОВАНИЙ}

Полученные результаты свидетельствуют о сложном строении разломной сети опорного участка Надежда (рис. 2, 3). Одним из основных ее элементов являются субгоризонтальные и наклонные зоны пластических деформаций, интенсивного рассланцевания и смятия пород мощностью от десятков сантиметров до первых метров. Они зафиксированы в керне скважин и маркируют границы петрографически разнородных тектонических пластин. Особенность данных зон появление в них дистена (кианита), свидетельствующего о динамометаморфических преобразованиях пород в условиях локально проявленных высоких давлений, а также их проявление в парагенезисе со складчатыми структурами. Это, наряду со смещениями, установленными по керну скважин (например, рис. 3), позволяет интерпретировать их как надвиговые и взбросовые нарушения. Плоскости надвигов падают в севе- ро-восточном и восточном направлениях под углами от 0 до $30^{\circ}$. Соответственно, шарниры подавляющего большинства складчатых структур близгоризонтальны и ориентированы в северо-западном и север-северозападном направлениях.

Другим важным элементом разломной сети являются субвертикальные разрывные нарушения, представленные зонами повышенной трещиноватости, дробления и милонитизации пород мощностью от нескольких десятков сантиметров до десяти метров и более. Представление о строении сети субвертикальных разрывных нарушений участка позволяет получить синоптическая круговая диаграмма, построенная по замерам элементов залегания разломов, зафиксированных на дневной поверхности (рис. 4). Она позволяет констатировать, что наибольшее развитие на участке имеют дизъюнктивы северо-западной ориентировки с аз. пад. 30-60 (210-240) $\angle 70-90^{\circ}$ (максимум I, рис. 4). Следующие по значимости - субширотные и субмеридиональные нарушения. Первые из них имеют аз. пад. 340-350 (160-170) $\angle 75-90^{\circ}$ (максимум II, рис. 4). Вторые представлены двумя системами: аз. пад. $80 \angle 80^{\circ}$ (максимум III, рис. 4) и аз. пад. $285 \angle 70^{\circ}$ (максимум IV, рис. 4). Менее интенсивный максимум на диаграмме отвечает нарушениям с аз. пад. 310$320 \angle 70-80^{\circ}$ (максимум V, рис. 4).

Кинематические характеристики субвертикальных нарушений в большинстве своем неоднозначны. Из прямых данных, позволяющих судить о кинематике разрывов, можно отметить зеркала со штрихами скольжения. У дизъюнктивов северо-западного простирания они свидетельствуют о преобладании вертикальной компоненты смещения с незначительной сдвиговой составляющей. При этом в ряде случаев установлены признаки как взбросовых, так и сбросовых перемещений, причем количество последних значительно больше, что может свидетельствовать о более позднем времени их проявления. Штрихи на плоскостях широтного и меридионального направления указывают на то, что смещения по дизъюнктивам указанных ориентировок носили преимущественно сдвиговый характер с той или иной долей вертикальной компоненты. Наиболее показательной в этом плане является одна из точек за пределами опорного участка, где в зоне меридионального нарушения (аз. пад. $260 \angle 88^{\circ}$ ) был зафиксирован присдвиговый дуплекс со следами как сжатия, так и растяжения, что свидетельствует о том, что по плоскостям данного разлома происходили как левые, так и правые перемещения.

В целом, можно констатировать, что в геологоструктурном отношении участок представляет собой пакет надвиговых чешуй, осложненный более поздними крутопадающими разрывами различных направлений. Предполагается, что корневая зона надвигового пакета расположена за пределами участка, в долине р. Малая Столбовая, где наблюдается серия крутопадающих $\left(\angle 40-70^{\circ}\right)$ взбросов. Тектонические линзы, 


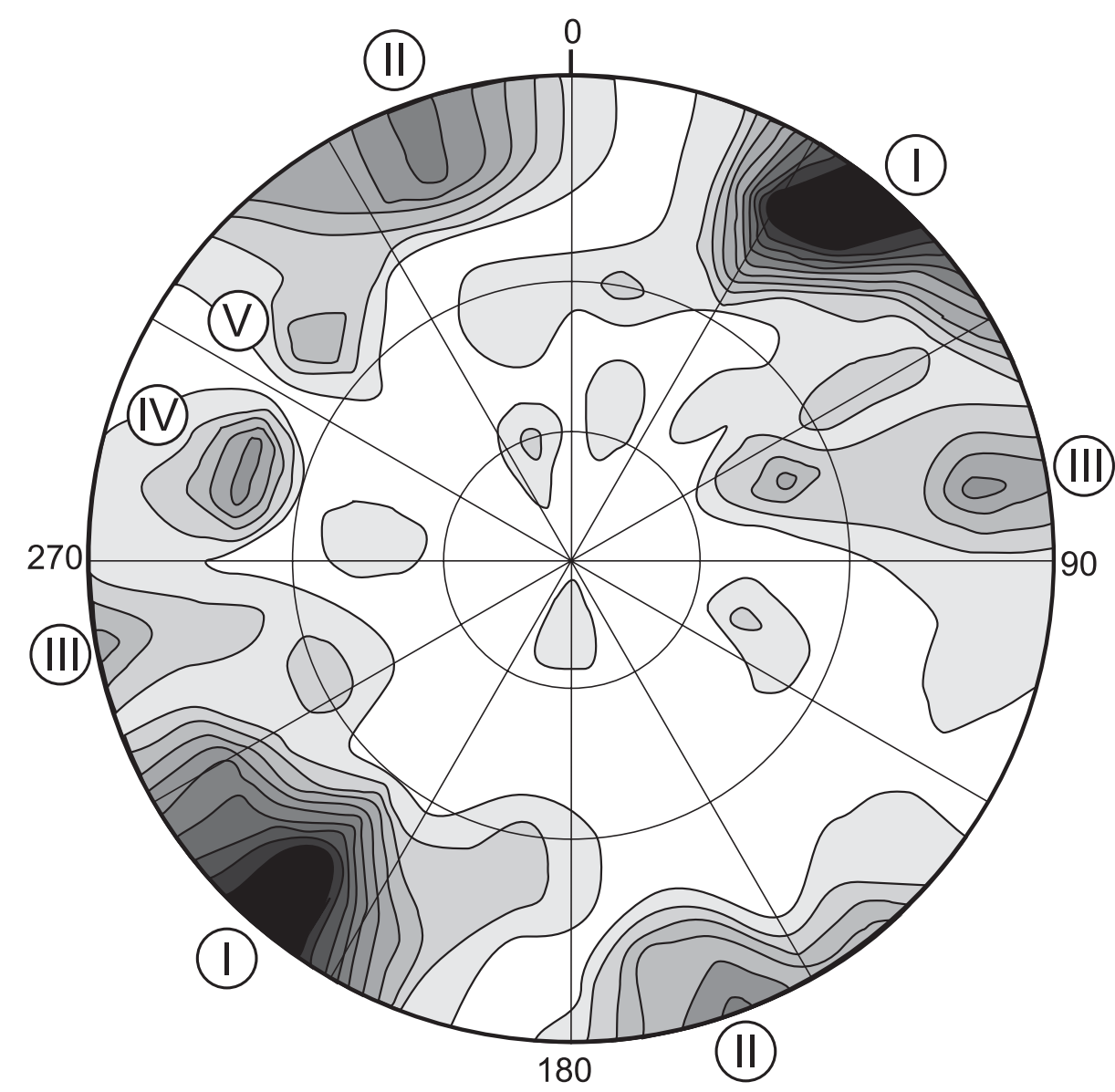

Рис. 4. Синоптическая диаграмма, построенная по замерам элементов залегания разломов, зафиксированных на дневной поверхности. Римскими цифрами обозначены максимумы, соответствующие системам крутопадающих разрывных нарушений, обсуждаемым в тексте.

Fig. 4. The synoptic diagram constructed from surface fault measurements. Roman numerals indicate maximums corresponding to the systems of steeply dipping faults discussed in the text.

сложенные вендскими песчаниками, вскрыты бурением на глубинах более 200 м от поверхности, что косвенно может указывать на большую мощность пакета надвиговых чешуй и весьма значительные масштабы чешуйчато-надвиговой структуры. Субвертикальные разломы, как правило, смещают надвиговые дизъюнктивы. Из них субмеридиональные нарушения являются подновленными и представляют собой элементы крупной региональной структуры, подчеркивающейся ориентировкой долин водотоков. Структурный план участка осложняют крутопадающие разрывы более мелкого ранга - преимущественно сбросы на восточном фланге и взбросы на западном.

Как указывалось выше, складчатые деформации также играют большую роль в структуре участка. Песчаники сяпякинской свиты смяты в относительно крупную (амплитуда более 130 м) пологую асимметричную антиклиналь с падением осевой плоскости на северо-восток под углами 20-50. Более мелкие складки широко распространены в пределах участка, шарниры большинства из них субгоризонтальны и ориентированы в северо-западном и север-северо-западном направлениях. Надвиги и складки участвуют в едином структурном парагенезе, что объясняет близость элементов их залегания. При этом складки северо-западного простирания были сформированы раньше и последующее наложение на них пликативных структур север-северо-западной ориентировки выразилось изгибами их крыльев и шарниров.

На изученном участке Тимша, в 30 км к северо-западу, чешуйчатые надвиги развиты среди карбонатных пород (известняки, мраморы, слюдисто-карбонатные сланцы) и метапелитов (хлорит-серицитовые сланцы) и выражены образованием брекчий, гофрировки, зеркал скольжения, «очковых» бластомилонитов с порфирокластами крупнозернистого кальцита в сланцеватом слюдисто-кальцитовом матриксе. На периферии надвиговых швов в подошве аллохтонов деформации выражены в образовании плитчатых мраморов с «альпийскими» прожилками и жилами крупнокристаллического кальцита. Плоскости надвигов по данным электротомографии 2D полого $\left(5-10^{\circ}\right)$ погружаются на восток.

Основой для восстановления и анализа полей тек- 
A

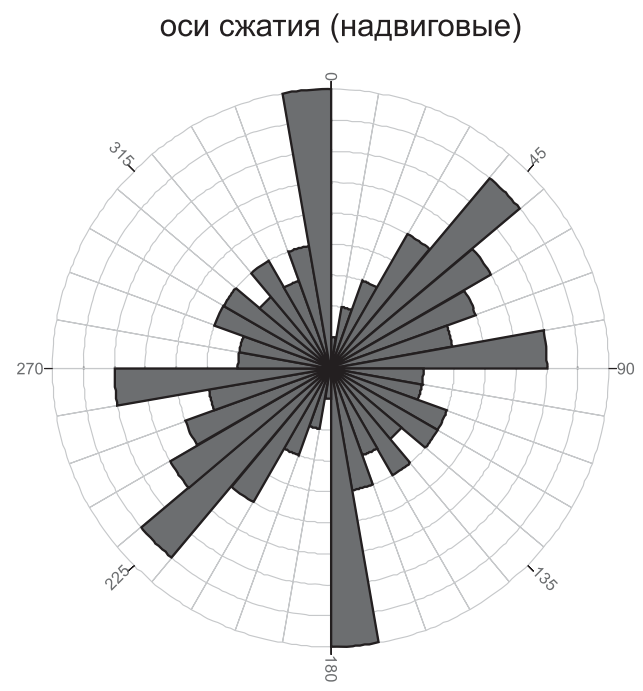

B

оси растяжения (сбросовые)

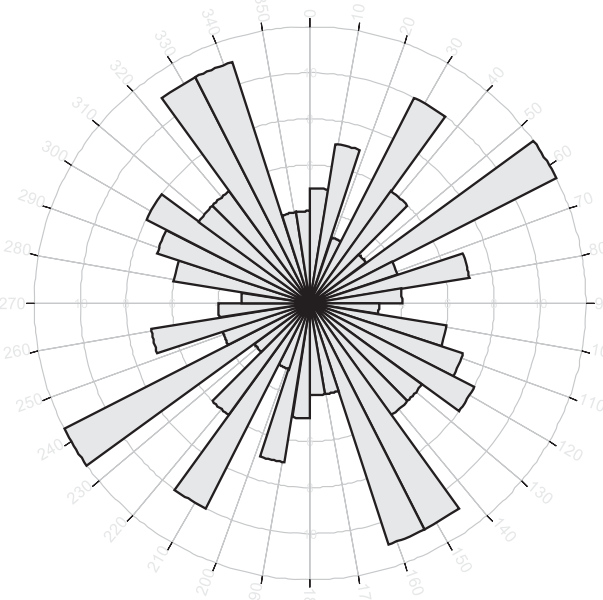

Б

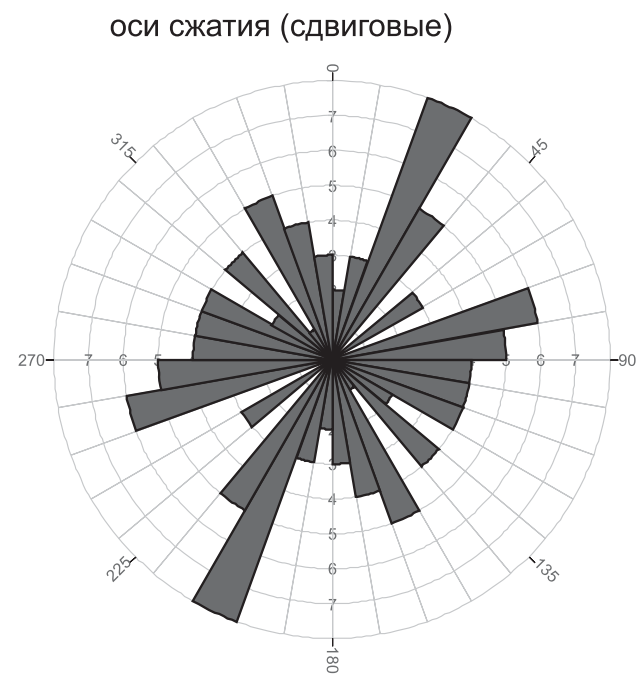

$\Gamma$

оси растяжения (сдвиговые)

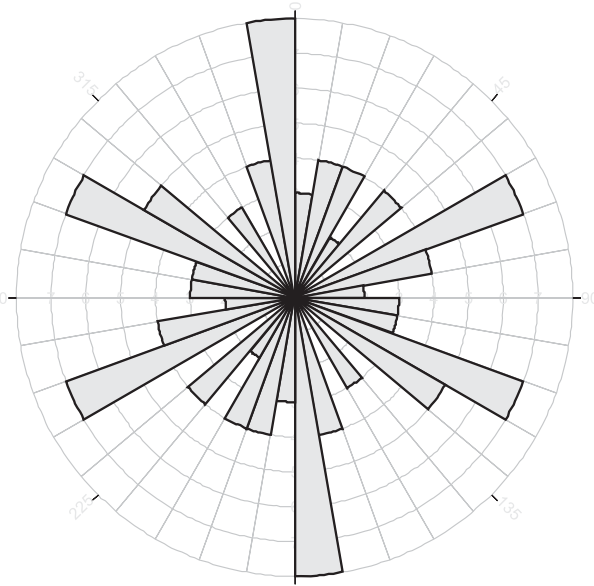

Рис. 5. Розы-диаграммы направлений субгоризонтальных осей главных нормальных напряжений. $A$ - оси сжатия в решениях надвигового типа; 5 - оси сжатия в решениях сдвигового типа, $B$ - оси растяжения в решениях сбросового типа; $\Gamma$ - оси растяжения в решениях сдвигового типа.

Fig. 5. Rose diagrams showing directions of sub-horizontal axes of major normal stresses. $A$ - compression axes in solutions for thrusts; $\square-$ compression axes in solutions for strike-slip faults; $B$ - extension axes in solutions for normal faults; $\Gamma$ - extension axis in solutions for strike-slip faults.

тонических напряжений послужили диаграммы массовых замеров тектонической трещиноватости, построенные для 60 точек наблюдений. На них при помощи ряда методических приемов [Nikolaev, 1977; Danilovich, 1961; Gladkov, Seminsky, 1999; Seminsky et al., 2005] были выделены сопряженные системы трещин. Для решения этой задачи проводился анализ максимумов систем трещин, их сочетаний и форм, а также, в случае их асимметрии, анализировались направления разбросов. Их реконструкция по сопряженным системам трещин [Gzovsky, 1975] позволила выявить поля напряжений сдвигового (оси сжатия $\sigma_{3}$ и растяжения $\sigma_{1}$ субгоризонтальны, промежуточная ось $\sigma_{2}$ субвертикальна), сбросового (оси $\sigma_{1}$ и $\sigma_{2}$ субгоризонтальны, ось $\sigma_{3}$ субвертикальна) и взбросового (оси $\sigma_{3}$ и $\sigma_{2}$ субгоризонтальны, ось $\sigma_{2}$ субвертикальна) типов (рис. 5). Разновариантность полученных решений в каждой из точек наблюдений косвенно свидетельствует о том, что формирование сети разрывных нарушений и ее последующая активизация происходили в течение нескольких этапов под действием разновекторных полей тектонических напряжений.

Дополнительно были рассмотрены взаимоотношения различных структурных элементов (разрывов и 


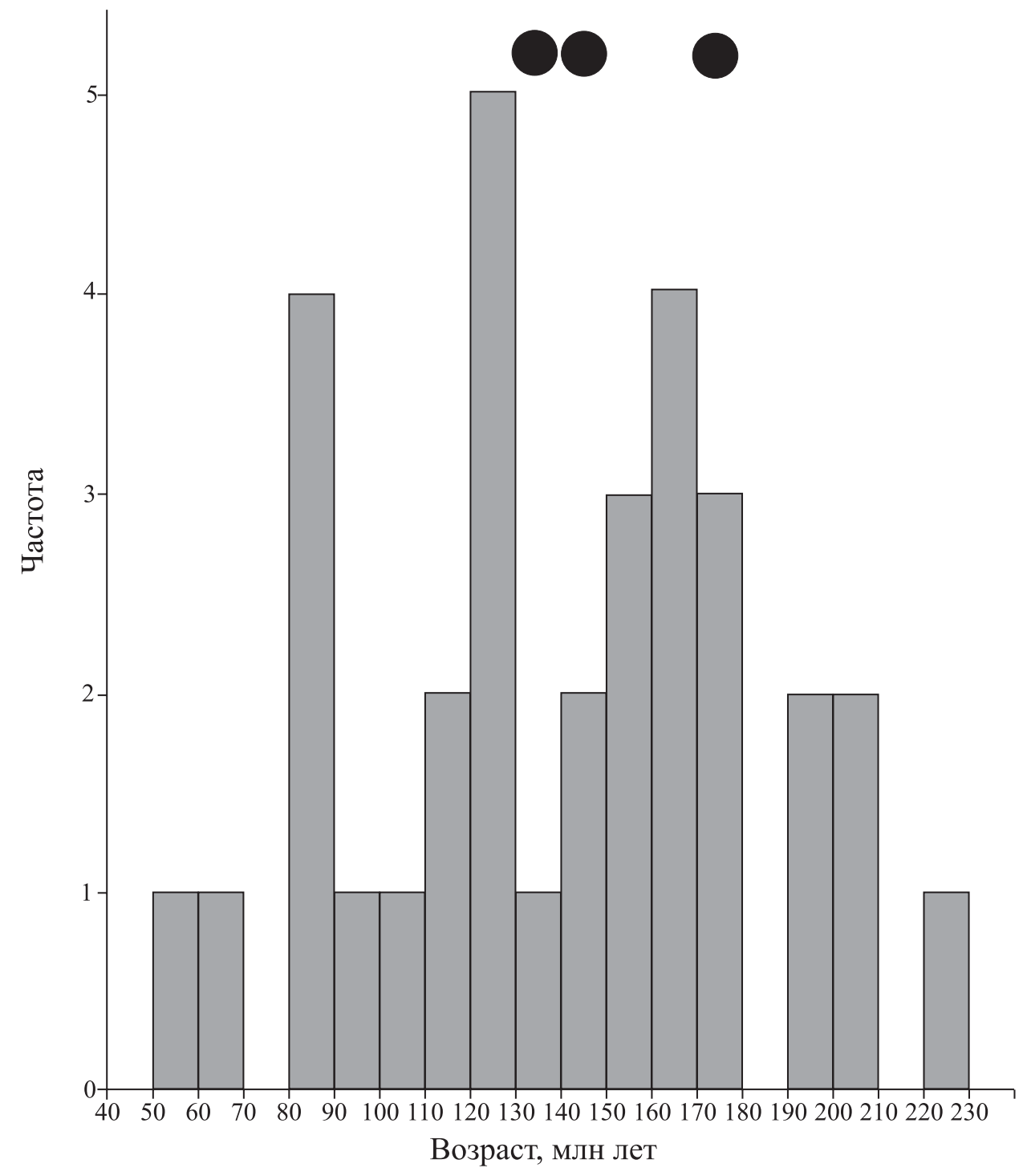

Рис. 6. Гистограмма K-Ar датировок кварц-полевошпатовых ортопород центральной части Приколымского террейна (по данным В.В. Акинина и И.Н. Котляра [Akinin, Kotlyar, 1997]). Кружками показаны датировки гранитов, прорывающих протерозойские и палеозойские толщи.

Fig. 6. The histogram of K-Ar dating of quartz-feldspar ortho-rocks of the central part of the Prikolyma terrain (according to data published by V.V. Akinina and I.N. Kotlyar [Akinin, Kotlyar, 1997]). Circles show dating of garnets penetrating through the Proterozoic and Paleozoic beds.

складок) и следов смещений (штрихи и борозды на плоскостях трещин, смещение маркеров и пр.), что вкупе с результатами анализа диаграмм трещиноватости позволило сделать вывод о том, что в истории формирования структуры участка последовательно выделяются четыре деформационных этапа. Наиболее ранний характеризовался сжатием в северо-восточном направлении, в результате которого образовались надвиги и складки северо-западной ориентировки, зоны зеленосланцевого динамометаморфизма. Участки наиболее сильного сжатия (стресса) маркируются появлением кианита. Пологие дислокации сопровождались субширотными и субмеридиональными сдвигами лево- и правосторонней ориентировки соответственно. На втором этапе ось сжатия приобрела восток-северо- восточную ориентировку, а растяжения - север-северо-западную, что отразилось в формировании субмеридиональных взбросов и надвигов север-северо-западного простирания. При этом по северо-западным нарушениям происходили взбросовые смещения со сдвиговой компонентой, по субширотным - преимущественно сбросовые подвижки, по северо-восточным - правые сдвиги. С третьим этапом связано формирование структур объемного растяжения в зоне сопряжения региональных разломов субширотного и субмеридионального направлений. Возникновение подобных структур обосновано теоретически и воспроизведено экспериментально [Seminsky et al., 2005]. В течение данного этапа ось сжатия имела северо-западную, а ось растяжения - северо-восточную ориентировку. 


\begin{tabular}{|c|c|c|c|c|}
\hline № этапа & $\begin{array}{c}\text { Ориентировка } \\
\text { осей главных } \\
\text { нормальных } \\
\text { напряжений }\end{array}$ & $\begin{array}{c}\text { Кинематические } \\
\text { характеристики } \\
\text { элементов } \\
\text { разрывной сети }\end{array}$ & $\begin{array}{c}\text { Время } \\
\text { действия }\end{array}$ & $\begin{array}{l}\text { События } \\
\text { геологической } \\
\text { истории террейна }\end{array}$ \\
\hline III & $\begin{array}{l}\text { коллизия Северо- } \\
\text { Азиатского, Северо- } \\
\text { Американского } \\
\text { кратонов и } \\
\text { Омолонского } \\
\text { микрократона }\end{array}$ \\
\hline IV
\end{tabular}
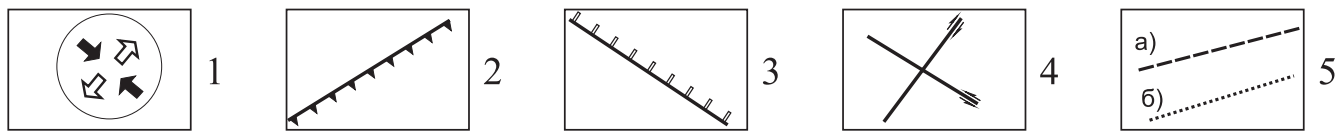

Рис. 7. Соотношение деформационных этапов по результатам тектонофизического анализа с событиями геологической истории Приколымского террейна. 1 - ориентировка осей сжатия (черные стрелки) и растяжения (белые стрелки и кружки); 2 - надвиги и взбросы; 3 - сбросы; 4 - сдвиги; 5 - проявления: процесса динамометаморфизма (a) и структур объемного растяжения (б).

Fig. 7. Correlation between deformation stages revealed from results of the tectonophysical analysis and events in the geological history of the Prikolyma terrain. 1 - orientations of compression axes (black arrows) and extension axes (white arrows and circles); 2 - thrusts and reverse faults; 3 - normal faults; 4 - strike-slip faults; 5 - evidences of dynamo-metamorphism (a) and volumetric extension structures (б).

Субширотные и субмеридиональные структуры активизировались как сдвиги (право- и левосторонние соответственно), северо-западные - как сбросы, а северовосточные - как взбросы. Развитие структур объемного растяжения благоприятствовало внедрению магматических тел и локализации прожилково-жильных образований. На завершающем этапе происходило сжатие в меридиональном направлении. При этом по субширотным нарушениям происходили надвиговые и взбросовые смещения, по субмеридиональным - сбросовые, по северо-восточным и северо-западным сдвиги (лево- и правосторонние соответственно).
Попытаемся параллелизовать выделенные деформационные этапы с историей геологического развития Приколымского террейна. Первый этап характеризовался развитием надвиговых зон рассланцевания и смятия, что дает основание считать его синметаморфическим. Формирование динамометаморфического комплекса Приколымья в последние годы традиционно датируется рифеем [Tkachenko, Berezner, 1995; Tkachenko, Shcherbakova, 1991; Shpikerman, 1998]. Однако нами установлено наложение динамометаморфических минеральных и структурных парагенезисов и на песчаники венда. Имеются также данные о том, что 
динамометаморфизм зеленосланцевой фации затрагивает и палеозойские породы, в основном вдоль зон крупных разломов [Protopopov, Kirillin, 1991; Shishkin, 1979]. Таким образом, есть основание выделять крупный этап сжатия, возрастные границы которого находятся в интервале от позднего рифея до раннего палеозоя; более точная геохронологическая привязка в силу недостатка информации проблематична. В течение данного этапа была сформирована структура динамометаморфического комплекса Приколымского террейна, включая долгоживущие субмеридиональные структуры. Позднерифейский орогенез и метаморфизм могли быть обусловлены аккреционным взаимодействием Северо-Азиатского континента и Омолонского микрократона [Shcherbakova et al., 1988], последовавшим вслед за распадом суперконтинента Родиния [Smelov, Timofeev, 2003]. Раннепалеозойские деформации следует связывать с коллизионным взаимодействием Северо-Азиатского и Северо-Американского кратонов [Khanchuk, 2006b; Shpikerman et al., 2001]. На следующем, позднепалеозойском, этапе разворот векторов сжатия - растяжения отразил обособление Приколымского террейна от окраины Северо-Азиатского кратона вследствие прогрессировавших процессов рифтогенеза [Bulgakova, 1991; Orlov et al., 2002; Tretyakov, 2004]. Такая геодинамическая интерпретация находится в согласии с палеомагнитными данными [Kolesov, 2003]. Кардинальная перестройка поля тектонических напряжений, переход к условиям общего растяжения на третьем этапе отразились в формировании гранитоидов и зон кварцевого прожилкования, в том числе золотоносных. Возрастные рамки этого этапа могут быть очерчены с помощью данных абсолютной геохронологии. Из имеющихся в базе ГЕОХРОН [Akinin, Kotlyar, 1997] K-Ar определений абсолютного возраста сравнительно однородных по минеральному и химическому составу [Shishkin, 1979] кварц-полевошпатовых ортопород центральной части Приколымского террейна (всего 33 определения) большинство (61 \%) находится в диапазоне 110-180 млн лет, что соответствует средней юре - раннему мелу (рис. 6). При относительно симметричном характере распределения датировок, максимум которых (61 \%) приходится на хронологический интервал 110-180 млн лет, обращает на себя внимание минимум на рубеже 130-140 млн лет. С позиций методики интерпретации K-Ar датировок, предложенной И.Н. Котляром и И.Л. Жулановой [Kotlyar et al., 2001], он указывает на происходившие в течение данного хронологического отрезка термальные события, приведшие к нарушению в породах однородности изотопных систем. Такими событиями могли стать внедрение гранитоидов и формирование гидротермальной минерализации. Таким образом, возраст третьего деформационного этапа можно принять соответствующим раннему мелу. Северо-западная ориентировка вектора сжатия однозначно позволяет увязать этот этап с региональным тангенциальным сжатием в результате косой коллизии Приколымского террейна с Омолонским микрократоном [Goryachev, 1998; Protopopov, 1997; Shpikerman, 1998]. Поворот вектора сжатия до субмеридионального направления с образованием многочисленных трещин северо-западной и северо-восточной ориентировки отразил проявление эпиорогенного рифтогенеза, в частности формирование Омсукчанского рифта [Kotlyar, Rusakova, 2004].

\section{5. ЗАКЛЮЧЕНИЕ}

Полевые тектонофизические исследования в бассейне р. Малая Столбовая позволили на качественно новом уровне рассмотреть особенности строения и развития разломной сети центральной части Приколымского террейна. Детальное изучение разнотипных разрывных нарушений, тектонической трещиноватости и складчатых структур позволило восстановить поля тектонических напряжений и наметить четыре деформационных этапа становления разрывной структуры региона в палеозое - мезозое.

Охарактеризованная достаточно напряженная деформационная история Приколымского террейна (рис. 7), охватывающая практически весь фанерозой, не позволяет рассматривать его в качестве жесткой консолидированной структуры. Все выделенные этапы формирования тектонической структуры Приколымья четко параллелизуются с главными тектономагматическими этапами развития северо-восточной окраины Северо-Азиатского кратона - позднепалеозойским и мезозойским. Приколымский террейн являлся «полноправным» участником этих грандиозных событий. Это определяет одинаковые состав и характер эволюции фанерозойского магматизма и металлогении, что весьма важно как в теоретическом, так и в прикладном аспекте.

\section{6. БЛАГОДАРНОСТИ}

Работа выполнена при поддержке Министерства образования и науки РФ (проекты №№ 2012-1.1-12000-2013-022 и 2012-1.2.2-12-000-1007-001).

\section{7. ЛИТЕРАТУРА}

Akimova E.D., 2006. Petrographic characteristics of metamorphic rocks in the Syapyakine and Edzhekal watershed. Vestnik YaGU 3 (3), 37-41 (in Russian) [Акимова Е.Д. Петрографическая характеристика метаморфических пород междуречья Сяпякинэ и Эджекал // Вестник ЯГУ. 2006. Т. 3. № 3. С. 37-41]. 
Akinin V.V., Kotlyar I.N., 1997. GEOCHRON - a computer database of isotopic dating of rocks, minerals and ores of the North-Eastern Russia. In: Magmatism and mineralization of the North-Eastern Russia. NEISRI, FEB RAS, Magadan, p. 313-318 (in Russian) [Акинин В.В., Котляр И.Н. «ГЕОХРОН» - компьютерная база данных изотопного датирования горных пород, минералов и руд северо-востока России // Магматизм и оруденение северо-востока России. Магадан: СВКНИИ ДВО РАН, 1997. С. 313-318].

Bulgakova M.D., 1991. The Early-Middle Paleozoic of the North-Eastern areas of the USSR (sedimentation analysis). Yakutian Scientific Centre, SB of the USSR Academy of Sciences, Yakutsk, 104 p. (in Russian) [Булгакова М.Д. Раннийсредний палеозой северо-востока СССР (седиментологический анализ). Якутск: ЯНЦ СО АН СССР, 1991. 104 c.].

Danilovich V.N., 1961. The Method of Belts in Studies of Fracturing Associated with Shearing. Irkutsk Polytechnic Institute, Irkutsk, 47 p. (in Russian) [Данилович В.Н. Метод поясов в исследовании трещиноватости, связанной с разрывными смещениями. Иркутск: Иркутский политехнический институт, 1961. 47 с.].

Gladkov A.S,. Seminsky K.Zh., 1999. Nontraditional analysis of fracturing girdles in mapping of near-horizontal fault zones, a case of the vicinity of the city of Irkutsk. Geologiya i Geofizika (Russian Geology and Geophysics) 40 (2), 213-220.

Goryachev N.A., 1998. Geology of the Mesozoic Gold-Quartz Vein Belts of the North Eastern Asia. NEISRI FEB RAS, Magadan, 210 p. (in Russian) [Горячев Н.А. Геология мезозойских золото-кварцевых жильных поясов северовостока Азии. Магадан: СВКНИИ ДВО РАН, 1998. 210 с.].

Grinberg G.A., Gusev G.S., Bakharev A.G. et al., 1981. Tectonics, Igneous and Metamorphic Complexes of the KolymaOmolon Massif. Nauka, Moscow, 357 p. (in Russian) [Гринберг Г.А. Тектоника, магматические и метаморфические комплексы Колымо-Омолонского массива. М.: Наука, 1981. 357 с.].

Gzovsky M.V., 1975. Fundamentals of Tectonophysics. Nauka, Moscow, 536 p. (in Russian) [Гзовский М.В. Основы тектонофизики. М.: Наука, 1975. 536 с.].

Khanchuk A.I., 2006a. Geodynamics, Magmatism and Metallogeny of the Eastern Russia. Dal'nauka, Vladivostok, V. 1., p. 1-572 (in Russian) [Ханчук А.И. Геодинамика, магматизм и металлогения востока России. Владивосток: Дальнаука, 2006. Книга 1. С. 1-572 ].

Khanchuk A.I., 2006b. Geodynamics, Magmatism and Metallogeny of the Eastern Russia. Dal'nauka, Vladivostok, V. 2., p. 573-981 (in Russian) [Ханчук А.И. Геодинамика, магматизм и металлогения востока России. Владивосток: Дальнаука, 2006. Книга 2. С. 573-981].

Kolesov E.V., 2003. Paleotectonic evolution of the North-Eastern region of Russia according to paleomagnetic data. In: Geodynamics, Magmatism and Minerageny of Continental Margins of the Northern Pacific Region. NEISRI FEB RAS, Magadan, V. 1, p. 101-103 (in Russian) [Колесов E.В. Палеотектоническая эволюция северо-восточного региона России по палеомагнитным данным // Геодинамика, магматизм и минерагения континентальных окраин севера Пацифики. Магадан: СВКНИИ ДВО РАН, 2003. Т. 1. С. 101-103].

Kotlyar I.N., Rusakova T.B., 2004. Cretaceous Magmatism and Ore-bearing Properties of the Okhotsk-Chukotka Region: Geological and Geochronological Correlations. NEISRI FEB RAS, Magadan, 152 p. (in Russian) [Котляр И.Н., Русакова Т.Б. Меловой магматизм и рудоносность Охотско-Чукотской области: геолого-геохронологическая корреляция. Магадан: СВКНИИ ДВО РАН, 2004. 152 с.].

Kotlyar I.N., Zhulanova I.L., Rusakova T.B., Gagieva A.M., 2001. Isotopic Systems of Igneous and Metamorphic Complexes of the North-Eastern Russia. NEISRI FEB RAS, Magadan, 319 р. (in Russian) [Котляр И.Н., Жуланова И.Л., Русакова Т.Б., Гагиева А.М. Изотопные системы магматических и метаморфических комплексов северо-востока России. Магадан: СВКНИИ ДВО РАН, 2001. 319 с.].

Nikolaev P.N., 1977. The method for statistical analyses of fractures and reconstruction of tectonic stress fields. Izvestiya VUZov. Geologiya i razvedka 12, 103-116 (in Russian) [Николаев П.Н. Методика статистического анализа трещин и реконструкция полей тектонических напряжений // Известия ВУЗов. Геология и разведка. 1977. № 12. С. 103116].

Orlov Yu.S., Trunilina V.A., Roev S.P., 2002. The Paleozoic magmatism in Eastern Yakutia: Geodynamic aspects. Otechestvennaya Geologiya 4, 50-54 (in Russian) [Орлов Ю.С., Трунилина В.А., Роев С.П. Палеозойский магматизм Восточной Якутии: геодинамические аспекты // Отечественная геология. 2002. № 4. С. 50-54].

Parfenov L.M., Berzin N.A., Khanchuk A.I., Badarch G., Belichenko V.G., Bulgatov A.N., Dril S.I., Kirillova G.L., Kuz'min M.I., Nokleberg W., Prokopiev A.V., Timofeev V.F., Tomurtogo O., Yang H., 2003. A model of formation of orogenic belts of Central and North Eastern Asia. Tikhookeanskaya Geologiya 22 (6), 7-41 (in Russian) [Парфенов Л.М., Берзин Н.А., Ханчук А.И., Бадарч Г., Беличенко В.Г., Булгатов А.Н., Дриль С.И., Кириллова Г.Л., Кузьмин М.И., Ноклеберг У., Прокопьев А.В., Тимофеев В.Ф., Томуртого О., Янь Х. Модель формирования орогенных поясов Центральной и Северо-Восточной Азии // Тихоокеанская геология. 2003. Т. 22. № 6. С. 7-41].

Parfenov V.D., Parfenova S.I., 1980. On reconstruction of axes of paleotectonic stresses in rocks. Doklady AN SSSR 251 (4), 238-241 (in Russian) [Парфенов В.Д., Парфенова С.И. К вопросу о реконструкции осей палеотектонических напряжений в горных породах // Доклады АН СССР. 1980. Т. 251. № 4. С. 238-241].

Protopopov R.I., 1997. The Late Mesozoic cross-structural magmatogenic-metasomatic zones of the Prikolymskoe uplift and the Berezovskaya suture zone, and their association with gold mineralization. In: Gold Mineralization and Granitoid Magmatism in the Northern Pacific Region: Abstracts of Reports at the All-Russia Conference in Magadan on 4-6 September 1997. NEISRI FEB RAS, Magadan, p. 62-63 (in Russian) [Протопопов Р.И. Позднемезозойские сквозьструктурные магматогенно-метасоматические зоны Приколымского поднятия и Березовской шовной зоны и 
связь с ними золотого оруденения // Золотое оруденение и гранитоидный магматизм Северной Пацифики: Тез. докл. Всероссийского совещания. Магадан, 4-6 сентября 1997 г. Магадан: СВКНИИ ДВО РАН, 1997. С. 62-63].

Protopopov R.I., Kirillin N.D., 1991. The tectonofacial analysis of the Prikolymskoe uplift. In: The Tectonofacial Analysis and Its Role in Geology, Geophysics, and Metallogeny: Proceedings of the $1^{\text {st }}$ All-Russia Tectonofacial Conference in Alma-Ata on 21-23 March 1989. Gylym, Alma-Ata, p. 130-137 (in Russian) [Протопопов Р.И., Кириллин Н.Д. Тектонофациальный анализ Приколымского поднятия // Тектонофациальный анализ и его роль в геологии, геофизике и металлогении: Материалы I Всероссийского тектонофациального совещания 21-23 марта 1989 г., Алма-Ата. Алма-Ата: Гылым, 1991. С. 130-137].

Rukovich V.N., Kolodeznikov I.I., 2006. Time series, material composition and specific petrochemical features of the preMesozoic igneous complexes of the Indigirka-Kolyma region. Vestnik YaGU 3 (3), 27-37 (in Russian) [Рукович В.Н., Колодезников И.И. Временные ряды, вещественный состав и петрохимические особенности домезозойских магматических комплексов Индигиро-Колымского региона // Вестник ЯГУ. 2006. Т. 3. № 3. С. 27-37].

Seminsky K.Zh., Gladkov A.S., Lunina O.V., Tugarina M.A., 2005. The Internal Structure of the Continental Fault Zones: Application Aspect. Publishing House of SB RAS, GEO Branch, Novosibirsk, 293 p. (in Russian) [Семинский К.Ж., Гладков А.С., Лунина О.В., Тугарина М.А. Внутренняя структура континентальных разломных зон: прикладной аспект. Новосибирск: Издательство СО РАН. Филиал «ГЕО», 2005. 293 с.].

Shcherbakova I.P., Berezner O.S., Beus V.A., Tkachenko V.I., 1988. The pre-Riphean metamorphic complex in Prikolymie. In: Igneous and Metamorphic Complexes of the North-Eastern Regions of the USSR and Compilation of Gosgeolkarta50 State Geological Map. NEISRI Far East of the USSR, Magadan, p. 75-76 (in Russian) [Щербакова И.П., Березнер O.С., Беус В.А., Ткаченко В.И. Дорифейский метаморфический комплекс в Приколымье // Магматические и метаморфические комплексы северо-востока СССР и составление Госгеолкарты-50. Магадан: СВКНИИ ДВО АН CCCP, 1988. С. 75-76].

Shishkin V.A., 1979. Metamorphic Complex of the Prikolymsky Uplift. Nauka, Moscow, 111 p. (in Russian) [Шишкин В.A. Метаморфический комплекс Приколымского поднятия. М.: Наука, 1979. 111 с.].

Shpikerman V.I., 1998. The Pre-Cretaceous Minerageny of the North-Eastern Asia. NEISRI FEB RAS, Magadan, 333 p. (in Russian) [Шиикерман В.И. Домеловая минерагения северо-востока Азии. Магадан: СВКНИИ ДВО РАН, 1998. 333 c.].

Shpikerman V.I., Goryachev N.A., Egorov V.N., 2001. On the Silurian orogeny, magmatism and metamorphism of the NorthEastern Asia. In: Problems of Geology and Metallogeny of the North-Eastern Asia at the Turn of the Millenniums. NEISRI FEB RAS, Magadan, V. 1, p. 102-103 (in Russian) [Шпикерман В.И., Горячев Н.А., Егоров В.Н. О силурийском тектогенезе, магматизме и метаморфизме на северо-востоке Азии // Проблемы геологии и металлогении северо-востока Азии на рубеже тысячелетий. Магадан: СВКНИИ ДВО РАН, 2001. Т. 1. С. 102-103].

Smelov A.P., Timofeev V.F., 2003. Terrain analysis and geodynamic model of formation of the North Asian craton in the Early Precambrian. Tikhookeanskaya Geologiya 22 (6), 42-55 (in Russian) [Смелов А.П., Тимофеев В.Ф. Террейновый анализ и геодинамическая модель формирования Северо-Азиатского кратона в раннем докембрии // Тихоокеанская геология. 2003. Т. 22. № 6. С. 42-55].

Tkachenko V.I., Berezner D.S., 1995. The Late Riphean riftogenic terrigenous-volcanogenic complex of Eastern Prikolymie. Otechestvennaya Geologiya 2, 37-44 (in Russian) [Ткаченко В.И., Березнер Д.С. Позднерифейский рифтогенный терригенно-вулканогенный комплекс Восточного Приколымья // Отечественная геология. 1995. № 2. С. 37-44].

Tkachenko V.I., Shcherbakova I.P., 1991. On the structure and metamorphism of the Precambrian Prikolymie. In: Metamorphic Complexes of the North-Eastern Regions of the USSR, Their Ore-Bearing Capacities, and Geological Mapping. NEISRI FEB RAS, Magadan, p. 74-87 (in Russian) [Ткаченко В.И., Щербакова И.П. О строении и метаморфизме докембрия Приколымья // Метаморфические комплексы северо-востока СССР, их рудоносность и геологическое картирование. Магадан: СВКНИИ ДВО РАН, 1991. С. 74-87].

Tretyakov F.F., 2004. The Early Paleozoic rift structures in the base of the Verkhoyansk folded belt. Otechestvennaya Geologiya 5, 57-60 (in Russian) [Третьяков Ф.Ф. Раннепалеозойские рифтовые структуры в основании Верхоянского складчатого пояса // Отечественная геология. 2004. № 5. C. 57-60].

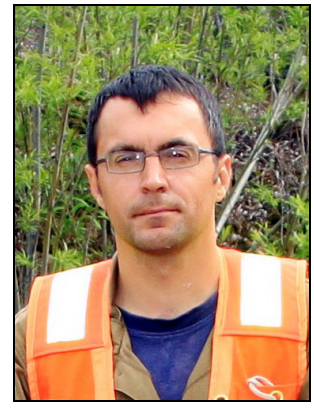

Глухов Антон Николаевич, канд. геол.-мин. наук

Северо-Восточный комплексный научно-исследовательский институт ДВО РАН

685000, Магадан, ул. Портовая, 16, Россия

Тел. 891485197 98; $\$ e-mail: gluhov76@list.ru

Glukhov, Anton N., Candidate of Geology and Mineralogy

Northeastern Interdisciplinary Scientific Research Institute, Far East Branch of RAS, Magadan, Russia

16 Portovaya street, Magadan 685000, Russia

Tel. 891485197 98; $₫$ e-mail: gluhov76@list.ru 


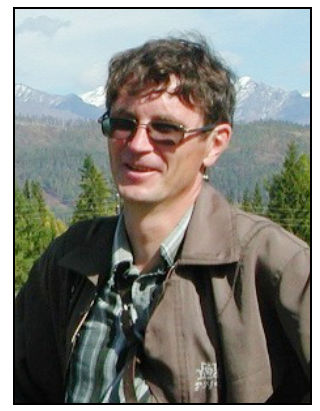

Гладков Андрей Станиславович, канд. геол.-мин. наук

Институт земной коры СО РАН

664033, Иркутск, ул. Лермонтова, 128, Россия

Тел. 891488524 28; e-mail: gladkov@crust.irk.ru

Gladkov, Andrey S., Candidate of Geology and Mineralogy

Institute of the Earth's Crust, Siberian Branch of RAS, Irkutsk, Russia

128 Lermontov street, Irkutsk 664033, Russia

Tel. 891488524 28; e-mail: gladkov@crust.irk.ru

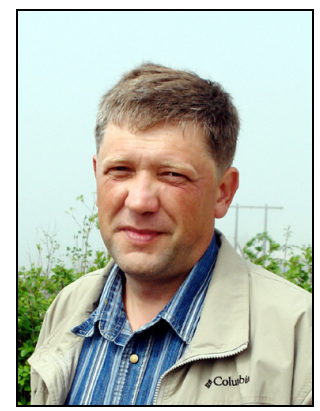

Кошкарев Денис Анатольевич, канд. геол.-мин. наук

Институт земной коры СО РАН

664033, Иркутск, ул. Лермонтова, 128, Россия

Тел. 891494647 04; e-mail: koshckar@crust.irk.ru

Koshkarev, Denis A., Candidate of Geology and Mineralogy

Institute of the Earth's Crust, Siberian Branch of RAS, Irkutsk, Russia

128 Lermontov street, Irkutsk 664033, Russia

Tel. 891494647 04; e-mail: koshckar@crust.irk.ru

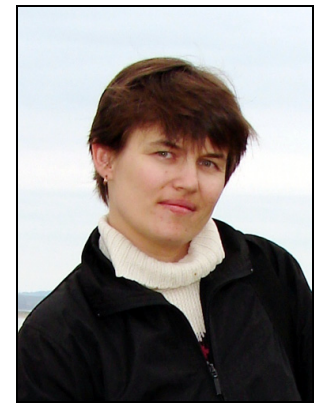

Лунина Оксана Викторовна, канд. геол.-мин. наук

Институт земной коры СО РАН

664033, Иркутск, ул. Лермонтова, 128, Россия

Тел. 891488524 09; e-mail: lounina@crust.irk.ru

Lunina, Oksana V., Candidate of Geology and Mineralogy

Institute of the Earth's Crust, Siberian Branch of RAS, Irkutsk, Russia

128 Lermontov street, Irkutsk 664033, Russia

Tel. 891488524 09; e-mail: lounina@crust.irk.ru 